\title{
Synthesis and characterization of sugar-based methacrylates and their random copolymers by ATRP
}

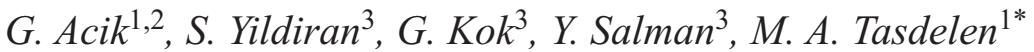 \\ ${ }^{1}$ Department of Polymer Engineering, Faculty of Engineering, Yalova University, TR-77100 Yalova, Turkey \\ ${ }^{2}$ Department of Chemistry, Faculty of Sciences and Letters, Piri Reis University, Tuzla, 34940 Istanbul, Turkey \\ ${ }^{3}$ Department of Chemistry, Faculty of Sciences, Ege University, Bornova, 35100 İzmir, Turkey
}

Received 17 February 2017; accepted in revised form 8 May 2017

\begin{abstract}
Various sugar-based methacrylate monomers have been prepared and randomly copolymerized with methyl methacrylate (MMA) using classical atom transfer radical polymerization (ATRP). Firstly, four different sugar-based methacrylates are synthesized by two-step method: (i) etherification of protected monosaccharides with epichlorohydrin and (ii) following ring-opening reaction of obtained epoxides with methacrylic acid (MAA) in the presence of triethylamine. Next, these monomers are copolymerized with MMA via ATRP at $90^{\circ} \mathrm{C}$ to obtain corresponding random copolymers. The molecular weights of the copolymers are determined by both GPC (gel permeation chromatography) and ${ }^{1} \mathrm{H}-\mathrm{NMR}$ (nuclear magnetic resonance spectroscopy) analyses and found as 10600 16800 and 12200 18500 g/mol, respectively. Moreover, the copolymer compositions are also determined by ${ }^{1} \mathrm{H}-\mathrm{NMR}$ analysis using characteristic signals of the monomers and found as about $94.1 \sim 97.8 \%$, which are good agreement with feeding ratio. In addition, the glass transition temperatures of copolymers are found as $101.2 \sim 102.9^{\circ} \mathrm{C}$ by changing type and composition of sugar-based methacrylate monomers. Overall, a series of well-defined random copolymers comprising different sugar-based methacrylates and methyl methacrylates were successfully synthesized by classical ATRP method.
\end{abstract}

Keywords: polymer synthesis, atom transfer radical polymerization, random copolymers, sugar based monomers

\section{Introduction}

Nearly all commercial polymers are produced from petroleum sources, but they may come from renewable resources in the future. Glycopolymers are synthetic polymers obtained from natural sugar based monomers and possess structural diversity, multiple functionalities and innocuousness for human health [1-4]. Because of their fascinating properties such as biocompatibility, low prices and readily available precursors, they have been utilized in medicine and biotechnology applications [5]. The commercial availability of a variety of carbohydrates provides access to a wide range of glycomonomer derivatives. The most common synthetic approaches are chemical connection of a vinyl group with a suitably protected carbohydrate, glycosylation of a halogenated sugar, Grignard reaction and enzymatic transesterification reactions [6]. Polymerization of these monomers can usually be achieved by free radical, controlled radical, anionic, cationic, ring-opening or ring-opening metathesis polymerization using monomers having pendant sugar units (glycomonomers) [7]. Among them, atom transfer radical polymerization (ATRP) permits the synthesis of well-defined (co)polymers from a wide selection of monomers and initiators under mild conditions [8-23]. To date, a number of well-defined glycopolymers from unprotected monomers have been successfully prepared by ATRP [24 28 ] or other controlled radical polymerization methods such as nitroxide mediated radical polymerization

$\overline{{ }^{*} \text { Corresponding author, e-mail: tasdelen@yalova.edu.tr }}$ C BME-PT 
(NMP) [29, 30], reversible addition-fragmentation chain transfer (RAFT) [31-34] and cyanoxyl-mediated radical polymerization $[35,36]$.

In the present study, a series of well-defined random copolymers comprising different sugar-based methacrylates and methyl methacrylates were synthesized by ATRP and their structures were investigated by spectroscopic, chromatographic and thermal analyses. For this purpose, four different sugarbased methacrylates were firstly synthesized by twostep method: (i) etherification of protected monosaccharides with epichlorohydrin and (ii) subsequent ring-opening reaction of the products with methacrylic acid. The successful ATRP of these monomers in the presence of methyl methacrylate enabled to prepare well-defined random copolymers. Finally, the structure of the resulting copolymers was verified by ${ }^{1} \mathrm{H}-\mathrm{NMR}$ spectroscopy, gel permeation chromatography and differential scanning calorimeter analyses.

\section{Experimental Part \\ 2.1. Materials}

D-Glucose, D-galactose and D-mannose were purchased from Merck EMD Millipore Corporation (Darmstadt, Germany) and used as received. Trichloroacetaldehyde (TCAA) was obtained by freshly distillation of chloral hydrate ( $\geq 98 \%$, Sigma-Aldrich Chemical Corporation, Steinheim, Germany) treating with sulphuric acid under inert atmosphere. Epichlorohydrin (ECH, $\geq 99.0 \%$ ), triethylamine (TEA, $\geq 99 \%$ ), tetrabutylammonium bromide (TBAB, $\geq 98 \%$ ), methacrylic acid (MAA, $\geq 99 \%$ ) were purchased from Merck EMD Millipore Corporation (Darmstadt, Germany). Dimethylformamide (DMF, $\geq 99.8 \%$, Sigma-Aldrich Chemical Corporation, Steinheim, Germany) was dried on 4A molecular sieve. Protected furanosidic sugars D-glufrn, D-manfrn, SD-glufrn, D-galfrn were prepared according to literature respectively [37-40]. TLC (thin layer chromatography) and column chromatography were performed on precoated aluminum plates (Merck 5554) and silicagel G-60 (Merck 9385) respectively. Hexane-ethyl acetate (7:3) was used for TLC and column chromatography. Methyl methacrylate (MMA, 99\%, SigmaAldrich Chemical Corporation, Steinheim, Germany) was passed through a basic alumina column to remove the inhibitor and stored in the freezer under nitrogen prior to use. $N, N, N^{\prime}, N^{\prime \prime}, N^{\prime \prime}$-Pentamethyldiethylenetriamine (PMDETA; 99\%, Sigma-Aldrich
Chemical Corporation, Steinheim, Germany) was used as ligand and distilled before to use. The metal catalyst, copper(I) chloride $(\mathrm{CuCl}, 99.99 \%$,SigmaAldrich Chemical Corporation, Steinheim, Germany) and the initiator, ethyl 2-bromopropionate (EtBrP, 99\%, Sigma-Aldrich Chemical Corporation, Steinheim, Germany) were used without any purification. All solvents were purified by conventional distillation and drying procedures.

\subsection{Instrumentation}

İntermediates of the ${ }^{1} \mathrm{H}-\mathrm{NMR}$ (Palo Alto, California, USA) analyses were recorded by a Varian $400 \mathrm{MHz}$ NMR spectrometer at room temperature in $\mathrm{CDCl}_{3}$ with tetramethylsilane as internal standard and chemical shifts were reported in ppm. The Perkin-Elmer (Waltham, USA) FT-IR Spectrum Two Spectrometer equipped with a diamond ATR device was used for Fourier transform infrared (FT-IR) analysis.

Gel permeation chromatography analyses were carried using a Viscotek GPCmax consisting of a pump module (GPCmax, Viscotek, Houston, TX) with flow rate $1 \mathrm{~mL} / \mathrm{min}$, a combined light-scattering (Model 270 dual detector, Viscotek), and a refractive index (RI) detector (VE 3580, Viscotek). Injections were done by an auto-sampler system, a $50 \mu \mathrm{L}$ injection volume was used. The RI detector was calibrated using narrow molecular weight polystyrene standards. The light-scattering detector $\left(\lambda_{0}=670 \mathrm{~nm}\right)$ included two scattering angles: 90 and 7. Two columns (LT5000L, Mixed, Medium Organic 300 $\times 8 \mathrm{~mm}$ and LT3000L, Mixed, Ultra-Low Organic $300 \times 8 \mathrm{~mm}$ ) with a guard column (TGuard, Organic Guard Column $10 \times 4.6 \mathrm{~mm}$ ) were used for the tetrahydrofuran eluent at $35^{\circ} \mathrm{C}$. The data were analyzed using Viscotek OmniSEC Omni-01 software. Differential scanning calorimetry (DSC) was performed on a PerkinElmer (Waltham, USA) Diamond equipment under nitrogen flow $(10 \mathrm{~mL} / \mathrm{min}$.) with a heating rate of $10^{\circ} \mathrm{C} / \mathrm{min}$.

\subsection{General procedure for etherification reactions of sugars with epichlorohydrin}

Epichlorohydrin (4 mL, $51 \mathrm{mmol})$, aq. $\mathrm{NaOH}(50 \%$, $10 \mathrm{~mL})$ and TBAB $(0.5 \mathrm{~g}, 1.6 \mathrm{mmol})$ were stirred for $30 \mathrm{~min}$ at r.t. Then corresponding protected sugars (D-glufrn, D-manfrn, SD-glufrn and D-galfrn) ( $2 \mathrm{~g}, 5.8 \mathrm{mmol}$ ) were added slowly to this mixture at approximately $5^{\circ} \mathrm{C}$ and the reaction continued at the same temperature for $1 \mathrm{~h}$, followed by an additional 
$2 \mathrm{~h}$. at r.t. The reaction mixture was poured over crushed ice and extracted with EtOAc $(4 \times 25 \mathrm{~mL})$. The organic phase was washed with aq. $\mathrm{NH}_{4} \mathrm{Cl}$ $(10 \%, 2 \times 2.5 \mathrm{~mL})$ and water $(2 \times 5 \mathrm{~mL})$, dried with anhydrous $\mathrm{Na}_{2} \mathrm{SO}_{4}$ and concentrated to give a syrup. The crude syrupy product was purified by flash column chromatography using Hexane - EtOAc (7:3) as eluent to give corresponding epoxy sugars as colorless syrups (77-89 yields).

\subsection{General procedure for ring-opening reactions of epoxy sugars with methacrylic acid}

Methacrylic acid (3.35 mL, $39.4 \mathrm{mmol})$ was added to a solution of epoxy sugar in $10 \mathrm{~mL}$ of DMF and then TEA $(0.7 \mathrm{~mL}, 5.1 \mathrm{mmol})$ was added drop-wise. The mixture was stirred for $24 \mathrm{~h}$. at $65^{\circ} \mathrm{C}$ and cooled by adding distilled cold water $(10 \mathrm{~mL})$. The resulting mixture was extracted with $\mathrm{CH}_{2} \mathrm{Cl}_{2}$, washed with water and dried over $\mathrm{Na}_{2} \mathrm{SO}_{4}$ and concentrated to give a syrup. The products were purified by flash chromatography. All the sugar-based methacrylic monomers were obtained as light yellow transparent gels (73-78\% yields). [41] The resulting monomers were characterized using FT-IR, ${ }^{1} \mathrm{H}-\mathrm{NMR}$ and ${ }^{13} \mathrm{C}-\mathrm{NMR}$ spectroscopies.

\subsubsection{D-glufrn-MA}

Colorless gel, $78 \%$ yield. $[\alpha]_{\mathrm{D}}^{21}:+0.86\left(\mathrm{c} 1, \mathrm{CH}_{2} \mathrm{Cl}_{2}\right)$; ${ }^{1} \mathrm{H}-\mathrm{NMR}\left(400 \mathrm{mHz}, \mathrm{CDCl}_{3}\right): \delta 6.21\left(\mathrm{~d}, 1 \mathrm{H}, J_{1,2}: 4 \mathrm{~Hz}\right.$, $\mathrm{H} 1), 6.13$ (bs, $1 \mathrm{H}, \mathrm{H}-\mathrm{CH}=\mathrm{C}<), 5.60(\mathrm{~s}, 1 \mathrm{H}$, $\left.\underline{\mathrm{H}}-\mathrm{C}-\mathrm{CCl}_{3}\right), 5.59$ (d, $1 \mathrm{H}, J: 1.6 \mathrm{~Hz}, \mathrm{H}-\mathrm{CH}=\mathrm{C}<$ ), $4.92\left(\mathrm{~d}, 1 \mathrm{H}, J_{2,3}: 0 \mathrm{~Hz}, \mathrm{H}_{2}\right), 4.33\left(\mathrm{dd}, 1 \mathrm{H}, J_{3,4}: 3 \mathrm{~Hz}\right.$, $\left.J_{4,5}: 7.2 \mathrm{~Hz}, \mathrm{H}_{4}\right), 3.95-4.24\left(\mathrm{~m}, 7 \mathrm{H}, \mathrm{H}_{3}, \mathrm{H}_{5}, \mathrm{H}_{6 \mathrm{a}}, \mathrm{H}_{6 \mathrm{~b}}\right.$, $\left.\mathrm{H}_{13}, \mathrm{H}_{14 \mathrm{a}}, \mathrm{H}_{14 \mathrm{~b}}\right), 3.50,3.65$ (dd, $1 \mathrm{H}, J_{12 \mathrm{a}, 12 \mathrm{~b}}: 10.8 \mathrm{~Hz}$, $J_{12 \mathrm{a}^{\prime}, 12 \mathrm{~b}}: 11.2 \mathrm{~Hz}, J_{12 \mathrm{a}, 13}: 8 \mathrm{~Hz}, J_{12 \mathrm{a}^{\prime}, 13}: 3.5 \mathrm{~Hz}, \mathrm{H}_{12 \mathrm{a}}$, $\left.\mathrm{H}_{12 \mathrm{a}^{\prime}}\right)$, 3.81, 3.91 (dd, $1 \mathrm{H}, J_{12 \mathrm{~b}, 13}: 3.2 \mathrm{~Hz}, J_{12 \mathrm{~b}^{\prime}, 13}$ : $5.2 \mathrm{~Hz}, \mathrm{H}_{12 \mathrm{~b}}, \mathrm{H}_{12 \mathrm{~b}}$ ), 1.95 (s, $3 \mathrm{H}$, methacr. $\mathrm{CH}_{3}$ ), 1.36, $1.44\left(2 \times\right.$ isopr. $\left.\mathrm{CH}_{3}\right) ;{ }^{13} \mathrm{C}-\mathrm{NMR}\left(\mathrm{CDCl}_{3}\right): \delta$ $167.20 \quad(>\mathrm{C}=\mathrm{O}), \quad 135.91 \quad\left(>\mathrm{C}=\mathrm{CH}_{2}\right), \quad 126.06$ $(>\mathrm{C}=\mathrm{CH} 2), 109.71,109.29$ ( $2 \times$ acetal carbons), $107.02\left(\mathrm{C}_{1}\right), 99.43\left(-\mathrm{CCl}_{3}\right), 25.02,26.82$ (2×isopr. $\mathrm{CH}_{3}$ ), 18.26 (methacr. $\mathrm{CH}_{3}$ ).

Anal. Calcd. for $\mathrm{C}_{18} \mathrm{H}_{25} \mathrm{Cl}_{3} \mathrm{O}_{6}$ : C, 43.97; $\mathrm{H}, 5.12$. Found: C, 44.29; H, 5.21

\subsubsection{D-manfrn-MA}

White solid, $75 \%$ yield. $M_{\mathrm{p}} 88-90{ }^{\circ} \mathrm{C} ;[\alpha]_{\mathrm{D}}^{21}-1.16$ (c $\left.1, \mathrm{CH}_{2} \mathrm{Cl}_{2}\right) ;{ }^{1} \mathrm{H}-\mathrm{NMR}\left(400 \mathrm{mHz}, \mathrm{CDCl}_{3}\right): \delta 5.92$ (d, $1 \mathrm{H}, J_{1,2}: 4 \mathrm{~Hz}, \mathrm{H}_{1}$ ) 6.11 (bs, $1 \mathrm{H}, \mathrm{H}-\mathrm{CH}=\mathrm{C}<$ ), $5.66\left(\mathrm{~s}, 1 \mathrm{H}, \underline{\mathrm{H}}-\mathrm{C}-\mathrm{CCl}_{3}\right), 5.57(\mathrm{~d}, 1 \mathrm{H}, J: 1.6 \mathrm{~Hz}$, $\mathrm{H}-\mathrm{CH}=\mathrm{C}<), 5.06\left(\mathrm{~d}, 1 \mathrm{H}, J_{2,3}: 5.6 \mathrm{~Hz}, \mathrm{H}_{2}\right), 4.47(\mathrm{~m}$, $\left.1 \mathrm{H}, \mathrm{H}_{5}\right), 3.92-4.27$ (m, 8H, $\mathrm{H}_{3}, \mathrm{H}_{4}, \mathrm{H}_{6 \mathrm{a}}, \mathrm{H}_{6 \mathrm{~b}}, \mathrm{H}_{12 \mathrm{~b}}$, $\left.\mathrm{H}_{13}, \mathrm{H}_{14 \mathrm{a}}, \mathrm{H}_{14 \mathrm{~b}}\right), 3.48,3.67$ (dd, $1 \mathrm{H}, J_{12 \mathrm{a}, 12 \mathrm{~b}}: 10.8 \mathrm{~Hz}$, $J_{12 \mathrm{a}, 12 \mathrm{~b}}: 11.2 \mathrm{~Hz}, J_{12 \mathrm{a}, 13}: 8 \mathrm{~Hz}, J_{12 \mathrm{a}, 13}: 3.5 \mathrm{~Hz}, \mathrm{H}_{12 \mathrm{a}}$, $\left.\mathrm{H}_{12 \mathrm{a}^{\prime}}\right), 1.93$ (s, 3H, methacr. $\left.\mathrm{CH}_{3}\right), 1.36,1.41$ (2×isopr. $\left.\mathrm{CH}_{3}\right) ;{ }^{13} \mathrm{C}-\mathrm{NMR}\left(\mathrm{CDCl}_{3}\right): \delta 167.16(>\mathrm{C}=\mathrm{O}), 135.86$ $\left(>\mathrm{C}=\mathrm{CH}_{2}\right), 126.01\left(>\mathrm{C}=\mathrm{CH}_{2}\right), 110.50,110.41(2 \times a c-$ etal carbons), $105.93\left(\mathrm{C}_{1}\right), 99.26\left(-\mathrm{CCl}_{3}\right), 27.09$, 25.52 (2×isopr. $\left.\mathrm{CH}_{3}\right), 18.22$ (methacr. $\mathrm{CH}_{3}$ ).

Anal. Calcd. for $\mathrm{C}_{18} \mathrm{H}_{25} \mathrm{Cl}_{3} \mathrm{O}_{6}: \mathrm{C}, 43.97 ; \mathrm{H}, 5.12$. Found: C, 44.02; H, 5.05

\subsubsection{SD-glufrn-MA}

Colorless gel, $78 \%$ yield. $[\alpha]_{\mathrm{D}}^{21}-0.59\left(\mathrm{c} 1, \mathrm{CH}_{2} \mathrm{Cl}_{2}\right)$; ${ }^{1} \mathrm{H}-\mathrm{NMR}\left(400 \mathrm{mHz}, \mathrm{CDCl}_{3}\right): \delta 6.10\left(\mathrm{~d}, 1 \mathrm{H}, J_{1,2}\right.$ : $\left.4 \mathrm{~Hz}, \mathrm{H}_{1}\right), 6.12$ (bs, $\left.1 \mathrm{H}, \mathrm{H}-\mathrm{CH}=\mathrm{C}<\right), 5.30(\mathrm{~s}, 1 \mathrm{H}$, $\left.\underline{\mathrm{H}}-\mathrm{C}-\mathrm{CCl}_{3}\right), 5.58(\mathrm{~d}, 1 \mathrm{H}, \mathrm{J}: 1.6 \mathrm{~Hz}, \mathrm{H}-\mathrm{CH}=\mathrm{C}<), 4.92$ (d, $1 \mathrm{H}, J_{2,3}: 0 \mathrm{~Hz}, \mathrm{H}_{2}$ ), 4.46 (dd, $1 \mathrm{H}, J_{3,4}: 3 \mathrm{~Hz}, J_{4,5}$ : $\left.7.2 \mathrm{~Hz}, \mathrm{H}_{4}\right), 3.94-4.34$ (m, 7H, $\mathrm{H}_{3}, \mathrm{H}_{5}, \mathrm{H}_{6 \mathrm{a}}, \mathrm{H}_{6 \mathrm{~b}}, \mathrm{H}_{13}$, $\left.\mathrm{H}_{14 \mathrm{a}}, \mathrm{H}_{14 \mathrm{~b}}\right), 3.49,3.63$ (dd, 1H, $J_{12 \mathrm{a}, 12 \mathrm{~b}}: 10.8 \mathrm{~Hz}$, $J_{12 \mathrm{a}^{\prime}, 12 \mathrm{~b}}{ }^{\prime}: 11.2 \mathrm{~Hz}, J_{12 \mathrm{a}, 13}: 8 \mathrm{~Hz}, J_{12 \mathrm{a}}, 13: 3.5 \mathrm{~Hz}, \mathrm{H}_{12 \mathrm{a}}$, $\left.\mathrm{H}_{12 \mathrm{a}^{\prime}}\right), 3.79,3.89$ (dd, $1 \mathrm{H}, J_{12 \mathrm{~b}, 13}: 3.2 \mathrm{~Hz}, J_{12 \mathrm{~b}}, 13$ : $5.2 \mathrm{~Hz}, \mathrm{H}_{12 \mathrm{~b}}, \mathrm{H}_{12 \mathrm{~b}}$ ), 1.94 ( $\mathrm{s}, 3 \mathrm{H}$, methacr. $\left.\mathrm{CH}_{3}\right), 1.39$, 1.34 (2×isopr. $\left.\mathrm{CH}_{3}\right) ;{ }^{13} \mathrm{C}$-NMR $\left(\mathrm{CDCl}_{3}\right): \delta 167.18$ $(>\mathrm{C}=\mathrm{O}), \quad 135.90 \quad\left(>\mathrm{C}=\mathrm{CH}_{2}\right), \quad 126.00 \quad\left(>\mathrm{C}=\mathrm{CH}_{2}\right)$, 109.62, 109.58 (2×acetal carbons), $106.29\left(\mathrm{C}_{1}\right)$, $96.83\left(-\mathrm{CCl}_{3}\right), 25.07,26.78$ (2×isopr. $\left.\mathrm{CH}_{3}\right), 18.24$ (methacr. $\mathrm{CH}_{3}$ ).

Anal. Calcd. for $\mathrm{C}_{18} \mathrm{H}_{25} \mathrm{Cl}_{3} \mathrm{O}_{6}: \mathrm{C}, 43.97 ; \mathrm{H}, 5.12$. Found: C, 43.29; H, 5.09

\subsubsection{D-galfrn-MA}

Colorless gel, $78 \%$ yield. $[\alpha]_{\mathrm{D}}^{21}-0.29\left(\mathrm{c} 1, \mathrm{CH}_{2} \mathrm{Cl}_{2}\right)$; ${ }^{1} \mathrm{H} \mathrm{NMR}\left(400 \mathrm{mHz}, \mathrm{CDCl}_{3}\right): \delta \quad 6.40 \quad(\mathrm{~s}, \quad 1 \mathrm{H}$, $\left.\underline{\mathrm{H}}-\mathrm{C}-\mathrm{CCl}_{3}\right), 6.19\left(\mathrm{~d}, 1 \mathrm{H}, J_{1,2}: 4 \mathrm{~Hz}, \mathrm{H}_{1}\right), 6.13$ (bs, $1 \mathrm{H}, \mathrm{H}-\mathrm{CH}=\mathrm{C}<), 5.58(\mathrm{~d}, 1 \mathrm{H}, \mathrm{J}: 1.6 \mathrm{~Hz}, \mathrm{H}-\mathrm{CH}=\mathrm{C}<$ ), $4.93\left(\mathrm{~d}, 1 \mathrm{H}, J_{2,3}: 0 \mathrm{~Hz}, \mathrm{H}_{2}\right), 3.95-4.41\left(\mathrm{~m}, 8 \mathrm{H}, \mathrm{H}_{3}\right.$, $\left.\mathrm{H}_{4}, \mathrm{H}_{5}, \mathrm{H}_{6 \mathrm{a}}, \mathrm{H}_{6 \mathrm{~b}}, \mathrm{H}_{13}, \mathrm{H}_{14 \mathrm{a}}, \mathrm{H}_{14 \mathrm{~b}}\right), 3.56,3.63(\mathrm{dd}, 1 \mathrm{H}$, $J_{12 \mathrm{a}, 12 \mathrm{~b}}: 10.8 \mathrm{~Hz}, J_{12 \mathrm{a}^{\prime}, 12 \mathrm{~b}}: 11.2 \mathrm{~Hz}, J_{12 \mathrm{a}, 13}: 8 \mathrm{~Hz}$, $\left.J_{12 \mathrm{a}, 13}: 3.5 \mathrm{~Hz}, \mathrm{H}_{12 \mathrm{a}}, \mathrm{H}_{12 \mathrm{~b}}\right), 3.69,3.81\left(\mathrm{dd}, 1 \mathrm{H}, J_{12 \mathrm{~b}, 13}\right.$ : $3.2 \mathrm{~Hz}, J_{12 \mathrm{~b}}, 13$ : $5.2 \mathrm{~Hz}, \mathrm{H}_{12 \mathrm{a}}, \mathrm{H}_{12 \mathrm{~b}}$ ), 1.95 (s, $3 \mathrm{H}$, methacr. $\left.\mathrm{CH}_{3}\right), 1.37,1.46\left(2 \times\right.$ isopr. $\left.\mathrm{CH}_{3}\right) ;{ }^{13} \mathrm{C}-\mathrm{NMR}$ $\left(\mathrm{CDCl}_{3}\right): \delta 167.21(>\mathrm{C}=\mathrm{O}), 135.93\left(>\mathrm{C}=\mathrm{CH}_{2}\right), 126.07$ $\left(>\mathrm{C}=\mathrm{CH}_{2}\right), 110.25,109.30$ (2×acetal carbons), 107.10 $\left(\mathrm{C}_{1}\right), 99.38\left(-\mathrm{CCl}_{3}\right), 25.03,26.42\left(2 \times\right.$ isopr. $\left.\mathrm{CH}_{3}\right)$, 18.41 (methacr. $\mathrm{CH}_{3}$ ).

Anal. Calcd. for $\mathrm{C}_{18} \mathrm{H}_{25} \mathrm{Cl}_{3} \mathrm{O}_{6}: \mathrm{C}, 43.97 ; \mathrm{H}, 5.12$. Found: $\mathrm{C}, 43.36$; H, 5.25 


\subsection{General procedure for random copolymerization of sugar-based methacrylates with methyl methacrylate} Firstly, sugar based monomer (for example D-glufrnMA, $\left.M_{\mathrm{W}}=477.71 \mathrm{~g} \cdot \mathrm{mol}^{-1}, 0.25 \mathrm{mmol}\right)$, and methyl methacrylate (MMA, $0.4 \mathrm{~mL}, 3.75 \mathrm{mmol}$ ) were dissolved in deoxygenated solvent (toluene, $0.5 \mathrm{~mL}$ ) and mixed with ligand (PMDETA, $12.5 \mu \mathrm{L}, 0.06 \mathrm{mmol}$ ), initiator (EtBrP, $2.94 \mu \mathrm{L}, 0.02 \mathrm{mmol}$ ) and catalysts $(\mathrm{Cu}(\mathrm{I}) \mathrm{Cl}, 2 \mathrm{mg}, 0.02 \mathrm{mmol})$. And then, the mixture was degassed by three freeze-pump-thaw cycles and placed in an oil bath $\left(90^{\circ} \mathrm{C}\right)$ for $4 \mathrm{~h}$. At the end of the reaction time by subjecting to air, the mixture was cooled to room temperature. Next, cooled mixture was diluted with THF and passed through a short silica column to remove copper salt. Then solvent was evaporated by rotary and concentrated product was precipitated in methanol, decanted and washed with methanol two times. The final product was dried under vacuum at ambient temperature for $24 \mathrm{~h}$.

\section{Results and discussion}

Due to the recently developed controlled polymerization techniques and click chemistry reactions, synthesis of tailor-made glycopolymers has become simpler and their biological properties can be easily adjusted as a function of the type of attached carbohydrates [42-44]. For instance, a series of phenylboronic acid-based block and random glycopolymers were prepared by RAFT polymerization and their self-assembled and drug-delivery properties were systematically studied [45]. By using similar monomer compositions, the block copolymers had a more regular transmittance change with the increasing glucose level compared to the random copolymers, however, the random copolymers exhibited a quicker insulin release rate than that of the block ones.

In this study, four different sugar-based methacrylates were firstly synthesized by two-step method: (i) etherification of protected monosaccharides 5,6$O$-isopropylidene-1,2-O-(R)-trichloroethylidene- $\alpha$ D-glucofuranose (D-glufrn), 5,6- $O$-isopropylidene1,2-O-trichloroethylidene- $\beta$-D-mannofuranose (Dmanfrn), 5,6-O-isopropylidene-1,2-O-(S)-trichloroethylidene- $\alpha$-D-glucofuranose (SD-glufrn), 5,6- $O$ isopropylidene-1,2- $O$-trichloroethylidene- $\alpha$-D-galactofuranose (D-galfrn), with epichlorohydrin and (ii) following ring-opening reaction of obtained epoxides with metharcylic acid in the presence of triethylamine. The synthetic route and structures of obtained sugar-based monomers (D-glufrn-MA, D-manfrnMA, SD-glufrn-MA and D-galfrn-MA) are given in Figure 1.

The chemical structures of synthesized sugar-based methacrylates were firstly characterized by FT-IR spectroscopy. As can be seen from Figure 2, the characteristic bands of monomers such as $\mathrm{O}-\mathrm{H}, \mathrm{C}-\mathrm{H}$, $\mathrm{C}=\mathrm{O}, \mathrm{C}=\mathrm{C}, \mathrm{C}-\mathrm{O}-\mathrm{C}$ and $\mathrm{C}-\mathrm{Cl}$ bonds were clearly appeared at 3450, 2930, 1710, 1610, 1175 and $720 \mathrm{~cm}^{-1}$, respectively. These results confirmed the presence of monosaccharide and methacrylate moieties in the obtained monomers.

The characteristic chemical shifts of sugar-based monomers obtained from ${ }^{1} \mathrm{H}-\mathrm{NMR}$ and ${ }^{13} \mathrm{C}$-NMR spectroscopies were given in experimental part (see Chapter 2.4). The specific chemical shifts belonging

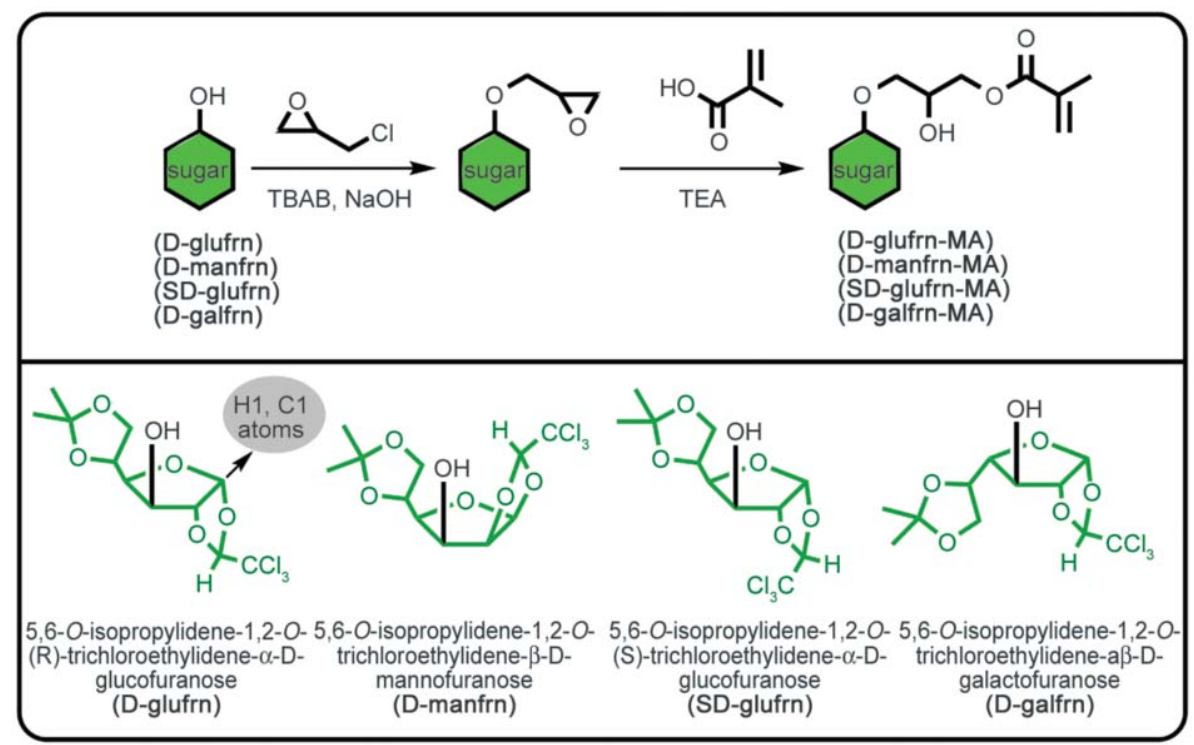

Figure 1. Synthetic pathway for the preparation of sugar based monomers 


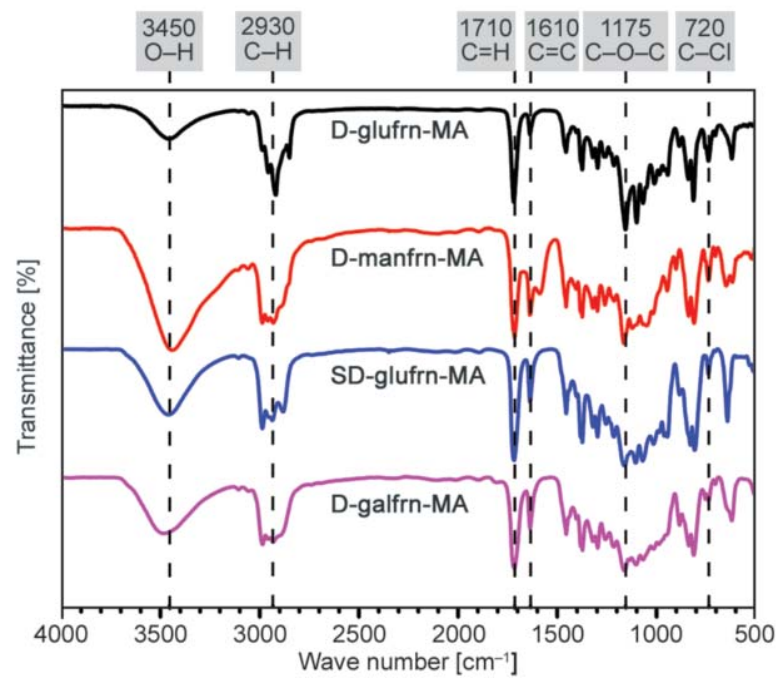

Figure 2. FT-IR spectra of D-glufrn-MA, D-manfrn-MA, SD-glufrn-MA and D-galfrn-MA

to acetal groups $\left(>\mathrm{CHCCl}_{3}\right)$ were assigned at 5.60, 5.66, 5.30 and $5.40 \mathrm{ppm}$, whereas the $\mathbf{H}-\mathbf{1}$ protons were detected at $6.21,5.92,6.10$ and $6.19 \mathrm{ppm}$. These shifts were in accordance with the literature data that were reported similar furanosidic trichloroethylidene acetals [46-50]. On the other hand, the characteristic protons of double bond and methyl groups of methacrylate were detected between 5.57-6.13 and $1.93-1.95 \mathrm{ppm}$, which confirmed the presence of methacrylate moieties on the monosaccharides. ${ }^{1} \mathrm{H}-\mathrm{NMR}$ and ${ }^{13} \mathrm{C}$-NMR spectra of D-glufrn-MA were presented in Figure 3, representatively.

Additionally, the characteristic chemical shifts of C-1, $\mathbf{C C l}_{3}$ and $\mathrm{C}\left(\mathrm{CH}_{3}\right)_{2}$ of sugar and methacrylate groups were determined by ${ }^{13} \mathrm{C}-\mathrm{NMR}$ spectroscopy and the data were given in experimental part (see Chapter 2.4). Overall, both ${ }^{1} \mathrm{H}-\mathrm{NMR}$ and ${ }^{13} \mathrm{C}-\mathrm{NMR}$ results proved the chemical structures of targeted sugar-based methacrylates via etherification and ring-opening reactions. After the successful synthesis of sugar-based methacrylates, their random
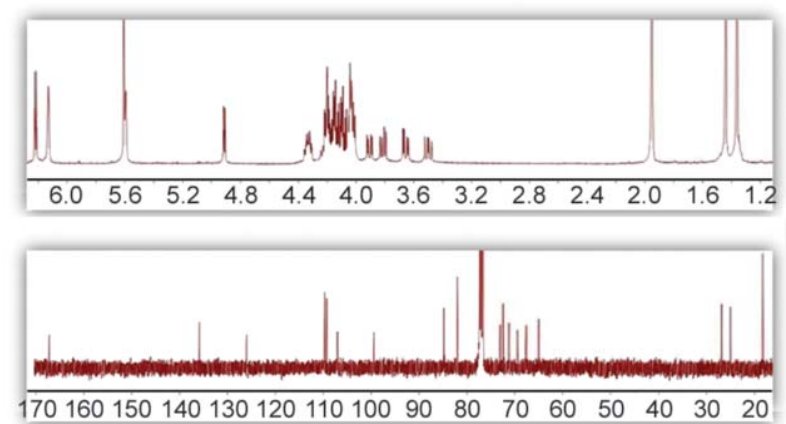

Figure 3. ${ }^{1} \mathrm{H}-\mathrm{NMR}$ and ${ }^{13} \mathrm{C}-\mathrm{NMR}$ spectra of D-glufrn-MA copolymerizations with methyl methacrylate (MMA) as a comonomer were investigated by classical atom transfer radical polymerization (ATRP) with a 200:1 monomer to initiator ratio. All polymerization reactions were initiated using ethyl 2-bromopropionate and complex of copper(I) chloride/ $N, N, N^{\prime}, N^{\prime}, N^{\prime \prime}$-pentamethyldiethylenetriamine $(1: 1: 3)$ at $90^{\circ} \mathrm{C}$ (Figure 4).

The FT-IR spectroscopy was used to further verify the functional groups of random copolymers, where all of them displayed the similar characteristic bands of MMA and sugar-based methacrylates; a broad band at $3450 \mathrm{~cm}^{-1}$ was assigned to $\mathrm{O}-\mathrm{H}$ stretching vibrations, a sharp band at $1710 \mathrm{~cm}^{-1}$ was related to $\mathrm{C}=\mathrm{O}$ stretching vibrations, a band at $1175 \mathrm{~cm}^{-1} 1$ was related to $\mathrm{C}-\mathrm{O}-\mathrm{C}$ stretching vibrations, a band at $2930 \mathrm{~cm}^{-1}$ was corresponded to asymmetric $\mathrm{C}-\mathrm{H}$ stretching vibrations and a band at $820 \mathrm{~cm}^{-1}$ was attributed to $\mathrm{C}-\mathrm{Cl}$ vibrations of sugar based monomer segments (Figure 5). In addition, the successful random copolymerizations were confirmed by the absence of the $\mathrm{C}=\mathrm{C}$ absorption bands at $1610 \mathrm{~cm}^{-1}$ in the resulting copolymers. Overall, the chemical compositions of random copolymers containing various functional groups such as alcohol, alkyl halide ether and ester were confirmed by FT-IR analysis.

The chemical structures of random copolymers were also confirmed by ${ }^{1} \mathrm{H}-\mathrm{NMR}$ analysis. As can be seen in Figure 6, the methyl $\left(-\mathrm{CH}_{3}\right)$ and methylene $\left(-\mathrm{CH}_{2}-\right)$ protons (a, $\mathbf{c}, \mathbf{d}, \mathbf{e}, \mathbf{f}, \mathbf{h}, \mathbf{j}$ and $\mathbf{u})$ of methacrylates were located between $0.5-2.0 \mathrm{ppm}$, whereas the characteristic methyl protons $\left(-\mathrm{O}-\mathrm{CH}_{3}\right)$ of MMA were apparently seen at $3.62 \mathrm{ppm}$. Additionally, the chemical shifts belonging to $\mathbf{H}-1(\mathbf{m})$ and $\mathrm{CHCCl}_{3}$ (t) of acetal groups of sugar methacrylates were detected at 5.63-5.91 and 6.05-6.21 ppm, respectively. On the other hand, the rest protons of methylene and methine groups of sugar methacrylates were detected between 3.71 and $4.52 \mathrm{ppm}$, which confirmed the presence of methacrylate moieties on the monosaccharides. Compositions of the random copolymers could be determined from the integration ratio of methoxy protons (d at $3.62 \mathrm{ppm}$ ) to that of the $\mathbf{H}-1$ protons ( $t$ at 5.63-5.91 ppm) [51]. The values for the composition determinations were about $94.1-97.8 \%$ and agreed well with feeding ratio (MMA:total monomer $=93.75: 100$ ). Furthermore, the molecular weight of copolymers could be also calculated from the relative intensities of the signals due to the methoxy ( $\mathbf{g}$ at $3.62 \mathrm{ppm}$ ) and $\mathbf{H}-1$ (t at 5.63-5.91 ppm) protons 

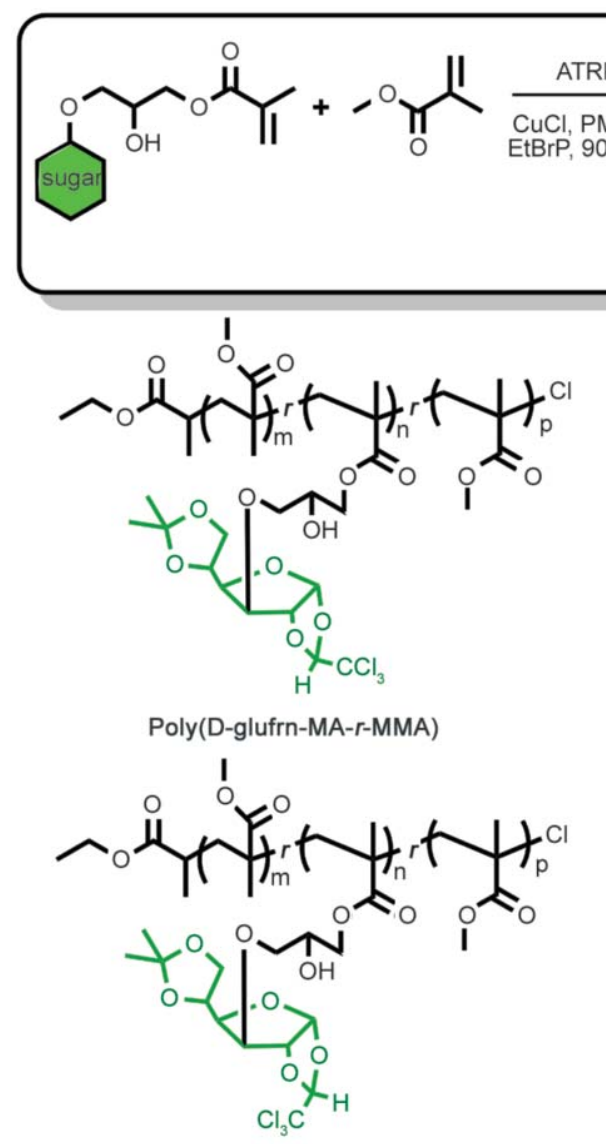

Poly(SD-glufrn-MA-r-MMA)
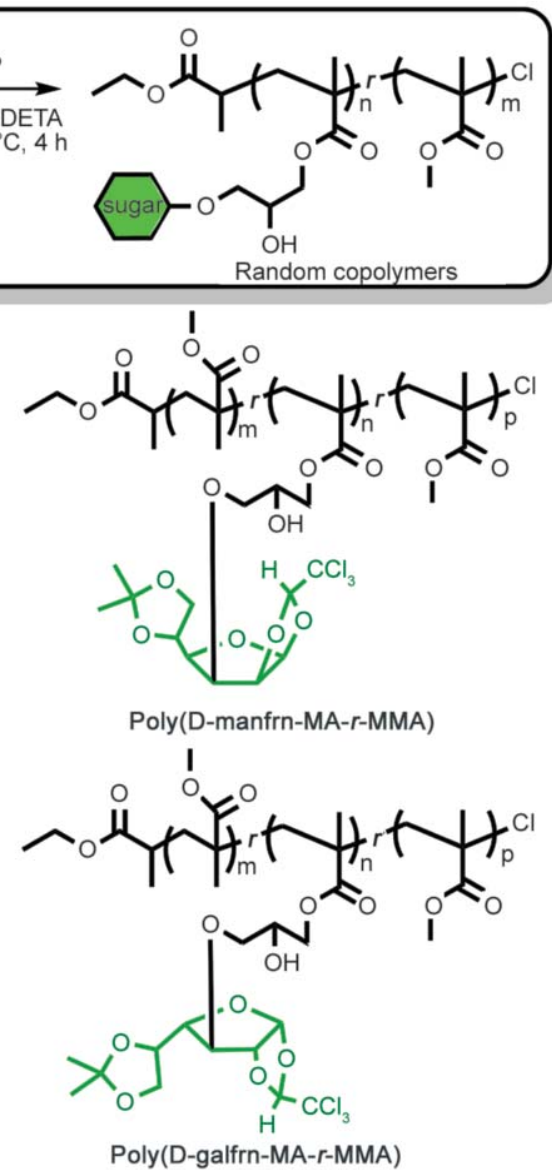

Figure 4. Random copolymerization of sugar-based monomers with MMA by ATRP and obtained copolymers

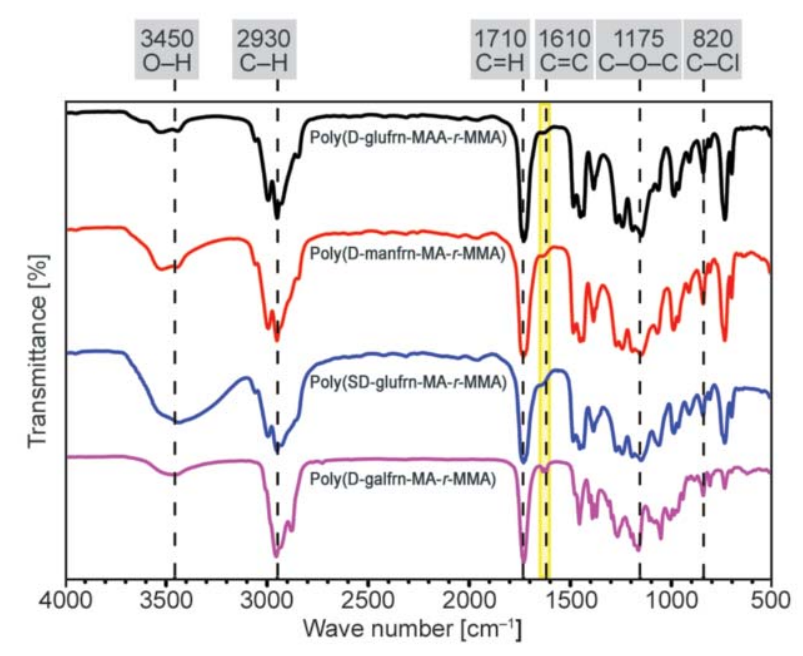

Figure 5. FT-IR spectra of poly(D-glufrn-MA-r-MMA), poly(D-manfrn-MA-r-MMA), poly(SD-glufrnMA-r-MMA) and poly(D-galfrn-MA-r-MMA)

of methacrylate monomers divided to the $\mathrm{CH}_{2}$ (b at $4.71 \mathrm{ppm})$ proton of the EtBrP initiator. According to Equation (1), the molecular weight is:

$M_{\mathrm{w}}=\frac{\frac{g}{3}}{2 b} \cdot 102.12+\frac{t}{2 b} \cdot 477.71$ where the letters represent the areas of the corresponding ${ }^{1} \mathrm{H}-\mathrm{NMR}$ peaks. Overall, the molecular characteristics of synthesized copolymers were successfully evaluated by ${ }^{1} \mathrm{H}-\mathrm{NMR}$ analysis.

In order to confirm the well-defined properties of random copolymers, their molecular weights and molecular weight distributions were investigated by gel permeation chromatography (GPC). As can be seen in Figure 7, all random copolymers displayed a GPC curve with monomodal and narrow size distribution. The molecular weights of the formed polymers were between 12.200 and $18.500 \mathrm{~g} / \mathrm{mol}$ with relatively narrow molecular weight distributions ranging from 1.30 1.45. Furthermore, the experimental molecular weight values of copolymers obtained from the ${ }^{1} \mathrm{H}-\mathrm{NMR}$ analyses were close to the theoretical values. A little differences between GPC and ${ }^{1} \mathrm{H}-\mathrm{NMR}$ data were usually observed for the differences in hydrodynamic volume of copolymer's components, in which sugar-based methacrylates had considerably dissimilar structures as compared to the MMA.

The thermal properties of the obtained random copolymers were evaluated using the glass transition temperatures $\left(T_{\mathrm{g}}\right)$ determined by DSC (Table 1$)$. Almost 


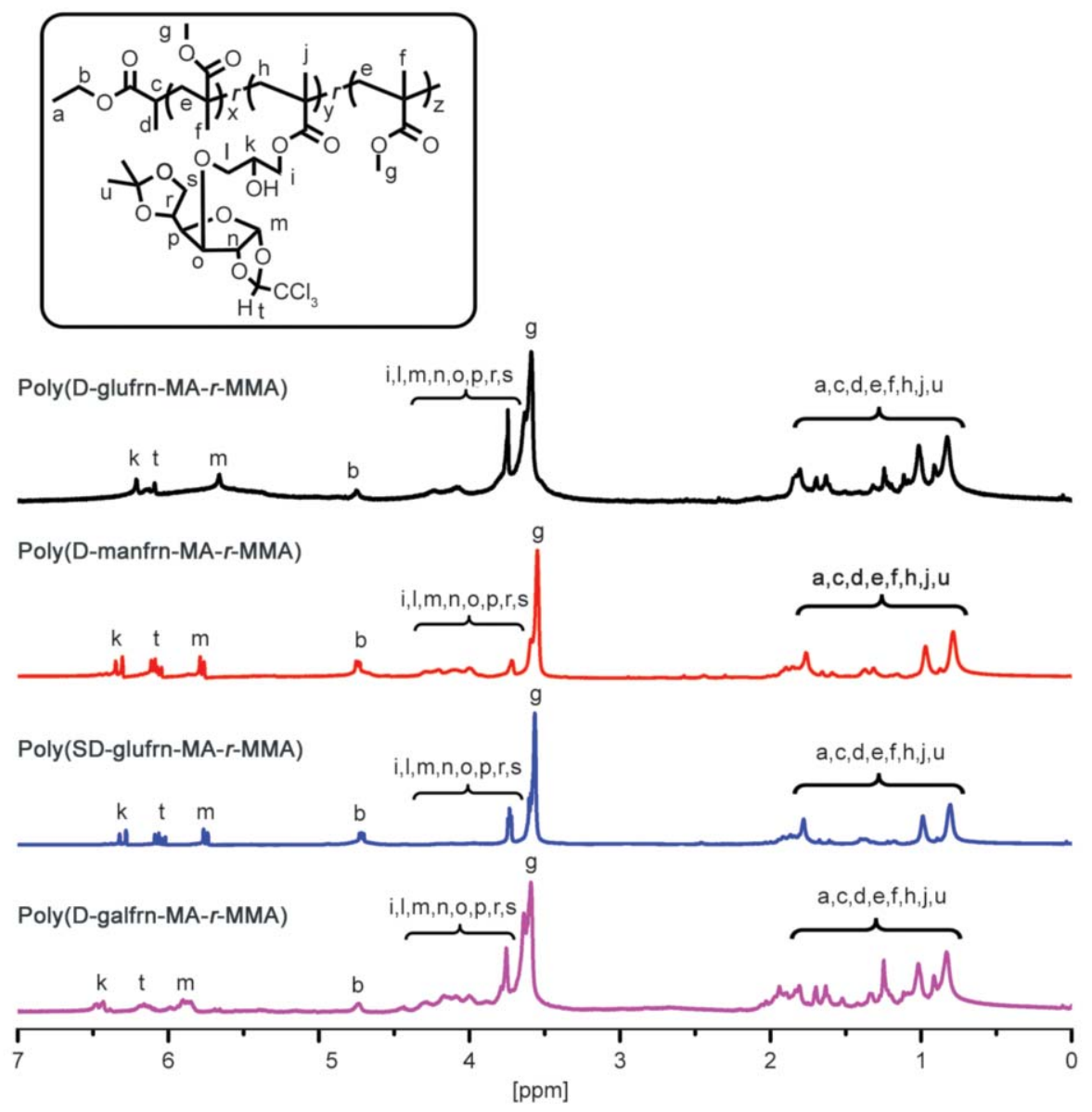

Figure 6. ${ }^{1} \mathrm{H}-\mathrm{NMR}$ spectra of poly(D-glufrn-MA-r-MMA), poly(D-manfrn-MA-r-MMA), poly(SD-glufrn-MA-r-MMA) and poly(D-galfrn-MA-r-MMA)

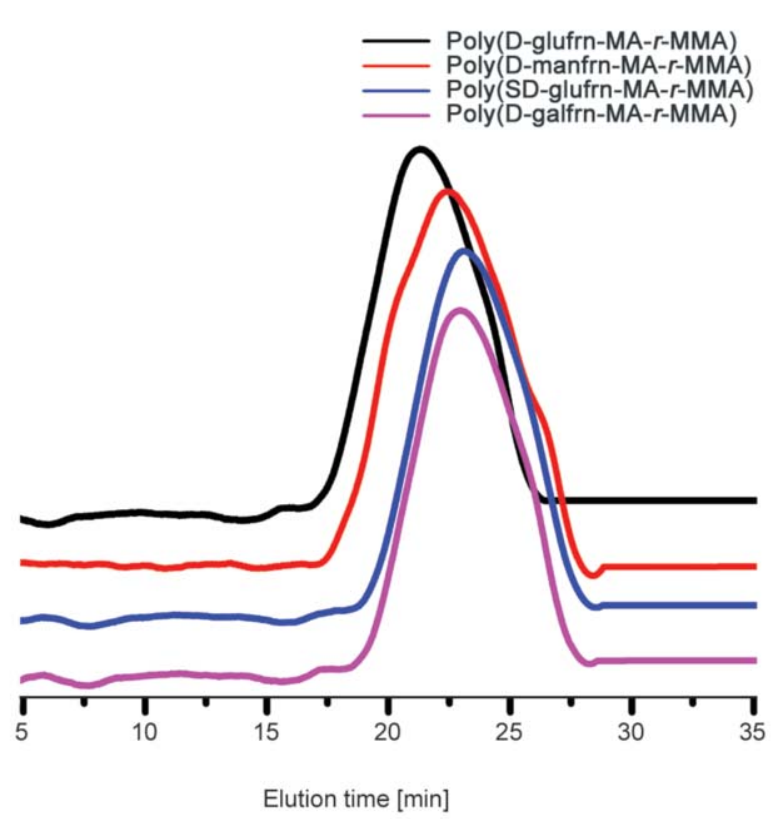

Figure 7. The GPC traces of poly(D-glufrn-MA-r-MMA), poly(D-manfrn-MA-r-MMA), poly(SD-glufrnMA-r-MMA), poly(D-galfrn-MA-r-MMA) random copolymers via ATRP. (All measurements were conducted using tetrahydrofuran as an eluent with flow rate, $1 \mathrm{~mL} \cdot \mathrm{min}^{-1}$ at $35^{\circ} \mathrm{C}$ ). all copolymers exhibited relatively similar $T g$ values between 101.2 and $102.9^{\circ} \mathrm{C}$ (entry 1-4). This differences could be related to either the molecular weight differences or nature of random copolymer with nonuniform composition, which was previously reported by other groups [52-54].

\section{Conclusions}

In conclusion, a series well-defined polymethacrylate-based random copolymers containing different methacrylates bearing protected furanosidic sugars with methyl methacrylate were successfully synthesized by ATRP. After the copolymerization, the molecular characteristics of resulting copolymers were determined by FT-IR, ${ }^{1} \mathrm{H}-\mathrm{NMR}, \mathrm{GPC}$ and DSC analyses. Their compositions were determined as 94.1 $97.8 \%$, which were agreed well with feeding ratio. On the other hand, the molecular weights, polydispersity and glass transition temperatures of the copolymers were about 10600 16800 g/mol, 1.30 1.45 and $101.2 \sim 102.9^{\circ} \mathrm{C}$ respectively. Due to their structural diversity, multiple functionalities and innocuousness, the synthesis of well-defined glycopolymers is 
Table 1. The random copolymerization of sugar-based methacrylates with methyl methacrylate by ATRP

\begin{tabular}{|c|c|c|c|c|c|c|c|}
\hline Copolymer & $\begin{array}{c}\text { Conv. }^{b} \\
{[\%]}\end{array}$ & $\begin{array}{c}M_{\mathbf{n}, \text { theo }}^{\mathrm{c}} \\
{\left[\mathrm{g} \cdot \mathbf{m o l}^{-1}\right]}\end{array}$ & $\begin{array}{c}M_{\mathrm{n}, \mathrm{NMR}}^{\mathrm{d}} \\
{\left[\mathrm{g} \cdot \mathrm{mol}^{-1}\right]}\end{array}$ & $\begin{array}{c}M_{\mathrm{n}, \mathrm{GPC}}^{\mathrm{e}} \\
{\left[\mathrm{g} \cdot \mathrm{mol}^{-1}\right]}\end{array}$ & $\boldsymbol{D}^{\mathrm{e}}$ & $\begin{array}{c}\text { MMA }^{\mathbf{f}} \\
{[\%]}\end{array}$ & $\begin{array}{c}T_{\mathrm{g}}^{\mathrm{g}} \\
{\left[{ }^{\circ} \mathbf{C}\right]}\end{array}$ \\
\hline Poly(D-glufrn-MA-r-MMA) & 65.1 & 16400 & 16800 & 18500 & 1.30 & 97.8 & 102.9 \\
\hline Poly(D-manfrn-MA-r-MMA) & 51.6 & 13100 & 13200 & 14800 & 1.45 & 97.4 & 101.8 \\
\hline Poly(SD-glufrn-MA-r-MMA) & 40.8 & 10400 & 10600 & 12200 & 1.33 & 96.5 & 101.2 \\
\hline Poly(D-galfrn-MA-r-MMA) & 50.4 & 12800 & 13400 & 14600 & 1.41 & 95.1 & 102.6 \\
\hline
\end{tabular}

${ }^{a}$ All polymerizations were conducted with MMA+SB-MA: EtBrP:CuCl:PMDETA: 200:1:1:3 ratio, at $90^{\circ} \mathrm{C}$ for $4 \mathrm{~h}$;

${ }^{\mathrm{b} C a l c u l a t e d}$ as gravimetrically;

${ }^{c}$ The molecular weights were calculated as follows:: $M_{\mathrm{n} \text {,theo }}=200 / 1 \cdot$ conversion $\cdot\left(M_{\mathrm{SB}-\mathrm{MA}}+M_{\mathrm{MMA}}\right)$;

${ }^{\mathrm{d}}$ The molecular weights $\left(M_{\mathrm{n}, \mathrm{NMR}}\right)$ were calculated using Equation (1) (from Figure 6);

${ }^{\mathrm{e}}$ The molecular weight $\left(M_{\mathrm{n}, \mathrm{GPC}}\right)$ and distribution $(\nexists)$ were determined by gel permeation chromatography;

${ }^{\mathrm{f}}$ Calculated from the integration ratio of $\mathbf{d}$ and $\mathbf{t}$ (from Figure 6);

${ }^{\mathrm{g}}$ Glass transition temperatures of the copolymers were determined by differential scanning calorimetry.

crucially important in many medicine and biotechnology applications.

\section{References}

[1] Miura Y., Hoshino Y., Seto H.: Glycopolymer nanobiotechnology. Chemical Reviews, 116, 1673-1692 (2016). https://doi.org/10.1021/acs.chemrev.5b00247

[2] Slavin S., Burns J., Haddleton D. M., Becer C. R.: Synthesis of glycopolymers via click reactions. European Polymer Journal, 47, 435-446 (2011). https://doi.org/10.1016/j.eurpolymj.2010.09.019

[3] Li X., Chen G.: Glycopolymer-based nanoparticles: Synthesis and application. Polymer Chemistry, 6, $1417-$ 1430 (2015). https://doi.org/10.1039/C4PY01740D

[4] Becer C. R.: The glycopolymer code: Synthesis of glycopolymers and multivalent carbohydrate-lectin interactions. Macromolecular Rapid Communications, 33, 742-752 (2012).

https://doi.org/10.1002/marc.201200055

[5] Ladmiral V., Melia E., Haddleton D. M.: Synthetic glycopolymers: An overview. European Polymer Journal, 40, 431-449 (2004).

https://doi.org/10.1016/j.eurpolymj.2003.10.019

[6] Wulff G., Schmid J., Venhoff T.: The synthesis of polymerizable vinyl sugars. Macromolecular Chemistry and Physics, 197, 259-274 (1996).

https://doi.org/10.1002/macp.1996.021970120

[7] Voit B., Appelhans D.: Glycopolymers of various architectures - More than mimicking nature. Macromolecular Chemistry and Physics, 211, 727-735 (2010). https://doi.org/10.1002/macp.201000007

[8] Matyjaszewski K.: Atom transfer radical polymerization (ATRP): Current status and future perspectives. Macromolecules, 45, 4015-4039 (2012).

https://doi.org/10.1021/ma3001719

[9] Pan X., Tasdelen M., Laun J., Junkers T., Yagci Y., Matyjaszewski K.: Photomediated controlled radical polymerization. Progress in Polymer Science, 62, 73125 (2016).

https://doi.org/10.1016/j.progpolymsci.2016.06.005
[10] Aydin M., Tasdelen M. A., Uyar T., Yagci Y.: In situ synthesis of $\mathrm{A}_{3}$-type star polymer/clay nanocomposites by atom transfer radical polymerization. Journal of Polymer Science Part A: Polymer Chemistry, 51, 5257-5262 (2013).

https://doi.org/10.1002/pola.26957

[11] Yagci Y., Tasdelen M. A., Jockusch S.: Reduction of $\mathrm{Cu}(\mathrm{II})$ by photochemically generated phosphonyl radicals to generate $\mathrm{Cu}(\mathrm{I})$ as catalyst for atom transfer radical polymerization and azide-alkyne cycloaddition click reactions. Polymer, 55, 3468-3474 (2014).

https://doi.org/10.1016/j.polymer.2014.06.068

[12] Tasdelen M. A., Yagci Y., Demirel A. L., Biedron T., Kubisa P.: Synthesis and characterization of block-graft copolymers [poly(epichlorohydrin- $b$-styrene)- $g$-poly (methyl methacrylate)] by combination of activated monomer polymerization, NMP and ATRP. Polymer Bulletin, 58, 653-663 (2007). https://doi.org/10.1007/s00289-006-0708-y

[13] Doganci E., Tasdelen M. A., Yilmaz F.: Synthesis of miktoarm star-shaped polymers with POSS core via a combination of CuAAC click chemistry, ATRP, and ROP techniques. Macromolecular Chemistry and Physics, 216, 1823-1830 (2015). https://doi.org/10.1002/macp.201500199

[14] Acik G., Tasdelen M. A.: Graft copolymers from commercial chlorinated polypropylene via $\mathrm{Cu}(0)$-mediated atom transfer radical polymerization. Polymer International, 65, 1458-1463 (2016). https://doi.org/10.1002/pi.5202

[15] Chmielarz P.: Cellulose-based graft copolymers prepared by simplified electrochemically mediated ATRP. Express Polymer Letters, 11, 140-151 (2017). https://doi.org/10.3144/expresspolymlett.2017.15

[16] Król P., Chmielarz P.: Recent advances in ATRP methods in relation to the synthesis of copolymer coating materials. Progress in Organic Coatings, 77, 913-948 (2014). https://doi.org/10.1016/j.porgcoat.2014.01.027 
[17] Gao H., Matyjaszewski K.: Synthesis of star polymers by a combination of ATRP and the 'click' coupling method. Macromolecules, 39, 4960-4965 (2006). https://doi.org/10.1021/ma060926c

[18] Chmielarz P.: Synthesis of $\alpha$ - $d$-glucose-based star polymers through simplified electrochemically mediated ATRP. Polymer, 102, 192-198 (2016).

https://doi.org/10.1016/j.polymer.2016.09.007

[19] von der Ehe C., Buś T., Weber C., Stumpf S., Bellstedt P., Hartlieb M., Schubert U. S., Gottschaldt M.: Glycopolymer-functionalized cryogels as catch and release devices for the pre-enrichment of pathogens. ACS Macro Letters, 5, 326-331 (2016).

https://doi.org/10.1021/acsmacrolett.5b00856

[20] von der Ehe C., Weber C., Gottschaldt M., Schubert U. S.: Immobilized glycopolymers: Synthesis, methods and applications. Progress in Polymer Science, 57, 64102 (2016).

https://doi.org/10.1016/j.progpolymsci.2016.02.001

[21] Xue H., Peng L., Dong Y., Zheng Y., Luan Y., Hu X., Chen G., Chen H.: Synthesis of star-glycopolymers by $\mathrm{Cu}(0)$-mediated radical polymerisation in the absence and presence of oxygen. RSC Advances, 7, 8484-8490 (2017).

https://doi.org/10.1039/C6RA28763H

[22] Yang Y., Hua C., Dong C-M.: Synthesis, self-assembly, and in vitro doxorubicin release behavior of dendronlike/linear/dendron-like poly( $\varepsilon$-caprolactone)- $b$-poly(ethylene glycol)- $b$-poly( $\varepsilon$-caprolactone) triblock copolymers. Biomacromolecules, 10, 2310-2318 (2009).

https://doi.org/10.1021/bm900497z

[23] Aksakal R., Resmini M., Becer C.: Pentablock star shaped polymers in less than 90 minutes via aqueous SET-LRP. Polymer Chemistry, 7, 171-175 (2016). https://doi.org/10.1039/C5PY01623A

[24] Ohno K., Tsujii Y., Fukuda T.: Synthesis of a well-defined glycopolymer by atom transfer radical polymerization. Journal of Polymer Science Part A: Polymer Chemistry, 36, 2473-2481 (1998).

https://doi.org/10.1002/(SICI)10990518(199810)36:14<2473::AID-POLA5>3.0.CO;2-U

[25] Liang Y-Z., Li Z-C., Chen G-Q., Li F-M.: Synthesis of well-defined poly [(2- $\beta$-D-glucopyranosyloxy) ethyl acrylate] by atom transfer radical polymerization. Polymer International, 48, 739-742 (1999).

https://doi.org/10.1002/(SICI)1097-

0126(199909)48:9<739::AID-PI283>3.0.CO;2-6

[26] Ladmiral V., Monaghan L., Mantovani G., Haddleton D. M.: $\alpha$-functional glycopolymers: New materials for (poly)peptide conjugation. Polymer, 46, 8536-8545 (2005).

https://doi.org/10.1016/j.polymer.2005.01.104

[27] Chen Y. M., Wulff G.: ABA and star amphiphilic block copolymers composed of polymethacrylate bearing a galactose fragment and poly( $\varepsilon$-caprolactone). Macromolecular Rapid Communications, 23, 59-63 (2002). https://doi.org/10.1002/1521-3927(20020101)23:1<59::AIDMARC59>3.0.CO;2-V
[28] Cui Y., Xu Y., Zhang J., Duan Q.: Synthesis and thermo-sensitive property of star poly $(N$-isopropylacrylamide) with $\alpha$-D-glucose-based group. Journal of Polymer Research, 23, 23/1-23/8 (2016).

https://doi.org/10.1007/s10965-016-0915-7

[29] Ohno K., Tsujii Y., Miyamoto T., Fukuda T., Goto M., Kobayashi K., Akaike T.: Synthesis of a well-defined glycopolymer by nitroxide-controlled free radical polymerization. Macromolecules, 31, 1064-1069 (1998). https://doi.org/10.1021/ma971329g

[30] Ting S. R. S., Min E. H., Escalé P., Save M., Billon L., Stenzel M. H.: Lectin recognizable biomaterials synthesized via nitroxide-mediated polymerization of a methacryloyl galactose monomer. Macromolecules, 42, 9422-9434 (2009).

https://doi.org/10.1021/ma9019015

[31] Lowe A. B., Sumerlin B. S., McCormick C. L.: The direct polymerization of 2-methacryloxyethyl glucoside via aqueous reversible addition-fragmentation chain transfer (RAFT) polymerization. Polymer, 44, 67616765 (2003). https://doi.org/10.1016/j.polymer.2003.08.039

[32] Albertin L., Kohlert C., Stenzel M., Foster L. J. R., Davis T. P.: Chemoenzymatic synthesis of narrow-polydispersity glycopolymers: Poly(6-O-vinyladipoyl- $d$-glucopyranose). Biomacromolecules, 5, 255-260 (2004). https://doi.org/10.1021/bm034199u

[33] Albertin L., Stenzel M. H., Barner-Kowollik C., Davis T. P.: Effect of an added base on (4-cyanopentanoic acid)-4-dithiobenzoate mediated RAFT polymerization in water. Polymer, 47, 1011-1019 (2006).

https://doi.org/10.1016/j.polymer.2005.12.069

[34] Escalé P., Ting S. R. S., Khoukh A., Rubatat L., Save M., Stenzel M. H., Billon L.: Synthetic route effect on macromolecular architecture: From block to gradient copolymers based on acryloyl galactose monomer using RAFT polymerization. Macromolecules, 44, 5911-5919 (2011). https://doi.org/10.1021/ma201208u

[35] Grande D., Baskaran S., Baskaran C., Gnanou Y., Chaikof E.: Glycosaminoglycan-mimetic biomaterials. 1. Nonsulfated and sulfated glycopolymers by cyanoxyl-mediated free-radical polymerization. Macromolecules, 33, 1123-1125 (2000). https://doi.org/10.1021/ma991579s

[36] Sun X-L., Grande D., Baskaran S., Hanson S. R., Chaikof E. L.: Glycosaminoglycan mimetic biomaterials. 4. Synthesis of sulfated lactose-based glycopolymers that exhibit anticoagulant activity. Biomacromolecules, 3, 1065-1070 (2002). https://doi.org/10.1021/bm025561s

[37] Anil H., Yüceer L.: Effects of the trichloromethyl group in displacement reactions of some 3-O-tosyl-1,2-O-tri chloroethylidene- $\alpha$ - $d$-galacto- and -gluco-furanose derivatives. Carbohydrate Research, 123, 315-319 (1983). https://doi.org/10.1016/0008-6215(83)88486-9 
[38] Salman Y. G., Kök G., Yüceer L.: Tricyclic furanoid dichloroacetyl orthoesters of d-mannose from 1,2-Otrichloroethylidene- $\beta$ - $d$-mannofuranose. Carbohydrate Research, 339, 1739-1745 (2004).

https://doi.org/10.1016/j.carres.2004.05.012

[39] Kök G., Karayıldırım T., Ay K., Ay E.: The KnoevenagelDoebner reaction on 1,2-O-(2,2,2-trichloroethylidene) derivatives of D-gluco- and D-manno- furanose. Molecules, 15, 7724-7731 (2010).

https://doi.org/10.3390/molecules 15117724

[40] Kök G., Salman Y. G.: A convenient synthesis of a cardiac sugar: 'D-digitalose'. Journal of Carbohydrate Chemistry, 31, 1-9 (2012).

https://doi.org/10.1080/07328303.2011.624285

[41] Ştefan L. M., Pană A. M., Pascariu M. C., Şişu E., Bandur G., Rusnac L. M.: Synthesis and characterization of a new methacrylic glycomonomer. Turkish Journal of Chemistry, 35, 757-767 (2011).

https://doi.org/10.3906/kim-1103-63

[42] Sunasee R., Adokoh C. K., Darkwa J., Narain R.: Therapeutic potential of carbohydrate-based polymeric and nanoparticle systems. Expert Opinion on Drug Delivery, 11, 867-884 (2014).

https://doi.org/10.1517/17425247.2014.902048

[43] Seymour L. W., Ferry D. R., Kerr D. J., Rea D., Whitlock M., Poyner R., Boivin C., Hesslewood S., Twelves C., Blackie R., Schatzlein A., Jodrell D., Bissett D., Calvert H., Lind M., Robbins A., Burtles S., Duncan R., Cassidy J.: Phase II studies of polymer-doxorubicin (PK1, FCE28068) in the treatment of breast, lung and colorectal cancer. International Journal of Oncology, 34, 1629 1636 (2009).

https://doi.org/10.3892/ijo_00000293

[44] McReynolds K. D., Gervay-Hague J.: Chemotherapeutic interventions targeting HIV interactions with hostassociated carbohydrates. Chemical Reviews, 107, 1533-1552 (2007).

https://doi.org/10.1021/cr0502652

[45] Guo Q., Zhang T., An J., Wu Z., Zhao Y., Dai X., Zhang X., Li C.: Block versus random amphiphilic glycopolymer nanopaticles as glucose-responsive vehicles. Biomacromolecules, 16, 3345-3356 (2015).

https://doi.org/10.1021/acs.biomac.5b01020

[46] Narain R., Armes S. P.: Synthesis and aqueous solution properties of novel sugar methacrylate-based homopolymers and block copolymers. Biomacromolecules, 4, 1746-1758 (2003).

https://doi.org/10.1021/bm034166e
[47] Narain R., Armes S. P.: Synthesis of low polydispersity, controlled-structure sugar methacrylate polymers under mild conditions without protecting group chemistry. Chemical Communications, 2002, 2776-2777 (2002). https://doi.org/10.1039/B208654A

[48] Ferreira L., Vidal M., Geraldes C., Gil M.: Preparation and characterisation of gels based on sucrose modified with glycidyl methacrylate. Carbohydrate Polymers, 41, 15-24 (2000). https://doi.org/10.1016/S0144-8617(99)00064-8

[49] Narain R., Housni A., Lane L.: Modification of carboxyl-functionalized single-walled carbon nanotubes with biocompatible, water-soluble phosphorylcholine and sugar-based polymers: Bioinspired nanorods. Journal of Polymer Science Part A: Polymer Chemistry, 44, 6558-6568 (2006).

https://doi.org/10.1002/pola.21727

[50] Muthukrishnan S., Mori H., Müller A. H.: Synthesis and characterization of methacrylate-type hyperbranched glycopolymers via self-condensing atom transfer radical copolymerization. Macromolecules, 38, 3108-3119 (2005).

https://doi.org/10.1021/ma050091q

[51] Hong S. C., Lutz J-F., Inoue Y., Strissel C., Nuyken O., Matyjaszewski K.: Use of an immobilized/soluble hybrid ATRP catalyst system for the preparation of block copolymers, random copolymers, and polymers with high degree of chain end functionality. Macromolecules, 36, 1075-1082 (2003).

https://doi.org/10.1021/ma021235t

[52] Ogura Y., Terashima T., Sawamoto M.: Synchronized tandem catalysis of living radical polymerization and transesterification: Methacrylate gradient copolymers with extremely broad glass transition temperature. ACS Macro Letters, 2, 985-989 (2013).

https://doi.org/10.1021/mz400484j

[53] Denizli B. K., Lutz J-F., Okrasa L., Pakula T., Guner A., Matyjaszewski K.: Properties of well-defined alternating and random copolymers of methacrylates and styrene prepared by controlled/living radical polymerization. Journal of Polymer Science Part A: Polymer Chemistry, 43, 3440-3446 (2005). https://doi.org/10.1002/pola.20824

[54] Teoh R. L., Guice K. B., Loo Y-L.: Atom transfer radical copolymerization of hydroxyethyl methacrylate and dimethylaminoethyl methacrylate in polar solvents. Macromolecules, 39, 8609-8615 (2006).

https://doi.org/10.1021/ma061650b 